\title{
PRACTICING CONTEXTUAL TEACHING AND LEARNING (CTL) APPROACH TO IMPROVE STUDENTS' READING COMPREHENSION IN RELATION TO MOTIVATION
}

\author{
Haerazi \\ Mandalika University of Education, Indonesia \\ Email: haerazi@ikipmataram.ac.id \\ Zukhairatunniswah Prayati \\ SMPN 1 Jonggat, Central Lombok, NTB, Indonesia \\ Email: prayati@gmail.com \\ Rully May Vikasari \\ SMPN 4 Praya, Central Lombok, NTB, Indonesia \\ Email:momvika@gmail.com
}

\begin{abstract}
APA Citation: Haerazi, H., Prayati, Z., \& Vikasari, R. M. (2019). Practicing contextual teaching and learning (CTL) approach to improve students' reading comprehension in relation to motivation. English Review: Journal of English Education, 8(1), 139-146. doi: 10.25134/erjee.v8i1.2011.
\end{abstract}

Received: 12-10-2019

Accepted: 17-11-2019

Published: 01-12-2019

\begin{abstract}
The need to acquire reading skills is increasing along with the needs of students to attain information. Therefore, this study aims at improving student's reading comprehension viewed from the motivation level using the contextual teaching and learning (CTL) approach at SMPN 1 Jonggat. To this end, a classroom action research consisting of two cycles was applied. Each cycle consisted of four stages, namely plans, actions, observations, and reflections. The subject of this study was the second-grader of SMPN 1 Jonggat, while the object of this study was the use of contextual teaching and learning (CTL) approach to improve students' reading comprehension in relation to motivation. The observation sheets, questionnaires, and reading tests were employed to collect the data. As result, the study showed that the use of CTL approach was effective to improve students' reading comprehension and motivation to learn. Students' achievement was 75 meaning that the passing grade enacted in the school was achieved. Meanwhile, the students' motivation to learn was at the high level as proven by the percentage of students' motivation which was at the standard value. Thus, it can be concluded that Contextual Teaching and Learning (CTL) approach can improve students' motivation to learn as well as their reading comprehension.

Keywords: CTL approach; reading comprehension; motivation.
\end{abstract}

\section{INTRODUCTION}

English has been becoming one of the compulsory subjects subjected to students at junior and upper secondary schools in Indonesia. Indonesian Ministry of Education and Culture has also enacted English as one of the subjects examined in the National examination for junior and upper secondary school students. In so doing, it is important for the students to acquire English competences. According to BSNP (2013), English learning in Indonesia was focused on the development of the four language skills, namely listening, speaking, reading, and writing.

Reading is one of the two receptive skills after listening. The need for reading is increasing along with the students' needs to acquire new information. Reading is even regarded as a primary source of EFL input that can improve the students' knowledge and discourse structure
(Nation, 2009; Haerazi et al., 2018). In this case, reading comprehension is defined as the ability to understand the content of a text through utilizing critical thinking and critical reading (Sultan et al., 2017; Alqatanani, 2017; Camp \& Camp. 2013; Tsai et al., 2013), the ability to understand the language of the text at word level, sentence level, and whole-text level (Par, 2018; Sprat et al., 2005), and the ability to comprehend texts using a set of schemata or their knowledge about the world while reading. Thus, comprehending a text is different from reading a text.

Further, one of the aspects that need to be considered in reading classes is students' motivation. Motivation is a kind of internal drive, pushing someone to do activities, such as reading or writing, in order to achieve the learning goals (Surastina \& Dedi, 2018). It is 'a set of cognitive arousal' which provokes a 'decision to act' as a 
result of which there is 'sustained intellectual and/or physical effort' so that person can achieve some 'previously set goal'. Hence, motivation is closely related to the achievement of students in learning as it becomes the determinant factor determining the success and failure of learning (Nugrahani, 2018).

Referring to those facts, English teachers are demanded to find an appropriate learning approach to develop reading comprehension. One of the learning approaches that can be applied in attaining the learning goals is contextual teaching and learning (CTL) approach. This approach emphasizes the process and content of reading (Satriani \& Emilia, 2012).

Teaching reading skills through contextual learning is promising to help students improve their vocabularies, linguistic features, and intellectual capacities. Thus, students may attain a deeper understanding so that they can contribute to their emotional development, intelligence and higher-order thinking skills (Thamrin \& Agustin, 2019; Mursyid \& Kurniawati, 2019).

Contextual teaching and learning is an approach which aims to help students understand the meaning of teaching materials based on the context of personal, social and cultural so that they have the knowledge/skills to actively construct their own understanding regarding the material given (Wandasari, 2011; Satriani \& Emilia, 2012).

The contextual teaching and learning approach is one of the learning approaches reflected in the student-centered approach. Syahid and Tuharto (2013) state the CTL approach is based on the constructivism philosophy. Therefore, contextual teaching and learning (CTL) is a theory which is based on the notion that learning can only occur when students are able to connect between content and context. By relating content and context from the inside and outside the classroom, the learning process becomes more relevant and meaningful for the students (Hosnan, 2014).

In this regard, Nurhadi (in Hosnan, 2014) elaborate five elements that should be taken into consideration while applying CTL approach in the class; namely 1) activating knowledge, 2) acquiring knowledge, 3) understanding knowledge, 4) applying knowledge, and 5) reflecting knowledge. These elements direct students to be more active to learn in the class. Contextually, reading activities based on these approach help students to develop their ideas from the text being read. In short, the CTL approach can be used to create learning activities to be more meaningful and real.

Accordingly, this study follows the components of CTL approach proposed by Hosnan (2014), namely constructivism, inquiry, questioning, learning community, modeling, reflecting, and authentic assessment. These components are then designed into teaching steps in a different order for teaching reading comprehension.

Referring to the background previously described, this study focuses on finding out the effectiveness of CTL approach to improve students' reading comprehension in relation to motivation to learn at the secondary schools of SMPN 1 Jonggat, Lombok Tengah. The novelty of this study lies on the use of contextual teaching and learning approach by applying some learning strategies in teaching reading comprehension viewed from the students' motivation to learn. The teaching strategies include the content of a text as a critical component that can be applied in group or individually. Besides, the learning strategies can engage students in the active language learning.

\section{METHOD}

This research adapted classroom action research (CAR) proposed by Cohen, Manion, and Morrison (2018). Based on the CAR model, each cycle of the actions consists of planning, acting, observing, and reflecting. Here, the researchers worked collaboratively with the English teachers in the school to explore their own context through a self-reflective, critical, and systematic approach. This research was conducted at the eighth-grade of SMPN 1 Jonggat, Lombok Tengah, West Nusa Tenggara (NTB). Basically, there are six classes of the eighth-grade. Yet, the research chose one class (8A class) to apply contextual teaching and learning (CTL).

The data of this research are qualitative data supported by quantitative data. The qualitative information presented the findings obtained from the learning processes during the implementation of the contextual learning and teaching (CTL) approach. These data were gained from the observation sheets reported in the form of field notes and interview transcripts. Meanwhile, the quantitative data come from the reading comprehension test and questionnaire dealing with the students' motivation. Regarding the two types of data, a phone-camera record was operated to record the classroom activities 
through photographs to provide a clearer picture of the actions. The data collection techniques and instruments used in this research can be seen in Table 1.

\section{Table 1. Data, technique, and instrument}

\begin{tabular}{lcc}
\hline \multicolumn{1}{c}{ Data } & Technique & Instrument \\
\hline a. Qualitative Data & & Observation Sheets \\
$\begin{array}{l}\text { Field notes reporting the instructional processes } \\
\text { that are focused on the teacher's performance }\end{array}$ & Observation & \\
and students' activities. & & \\
$\begin{array}{l}\text { Interview transcripts dealing with the teacher's } \\
\text { and students' opinions and expectations relating } \\
\text { to research instructions. }\end{array}$ & Interview & Interview Guidelines \\
b. Quantitative Data & & \\
$\begin{array}{l}\text { Reading comprehension tests in the form of pre- } \\
\text { test and post-test. }\end{array}$ & Tests & $\begin{array}{c}\text { Reading Comprehension } \\
\text { Tests }\end{array}$ \\
\hline
\end{tabular}

The data were then analyzed by using some steps proposed by Cohen, Manion, and Morrison (2018). Those steps consisted of reducing, displaying, drawing, and concluding. The researchers firstly sorted out the important and relevant data using coding technique. Then, the researchers displayed the result of the reduced data. At the end of these steps, the researchers drew conclusions based on the analysis. To validate the research data, the data coming from observation were cross-checked with the data collected from interview. The quantitative data were analyzed by conducting descriptive and inferential statistic. The descriptive statistic was used to find out the means of students' reading comprehension scores obtained from the pre-test and post-test.

\section{RESULTS AND DISCUSSION}

The action research applied the cyclical model that consisted of two main activities, namely preliminary and action. The action phase has four steps, namely planning, acting, observing, and reflecting. In the planning step, the researcher identified the teaching problems at SMPN 1 Jonggat. Here, the researchers worked collaboratively with the teachers to identify reading problems and determine which problems to solve. Then, the researchers designed the appropriate actions, lesson plans, and critical and standard competences.
Following the planning step, the researchers employed the actions. During the actions, the researchers acted as the observers, while the English teacher in the school acted as a teacher. Throughout the action, the observation process was happening. The contextual teaching, actions, students' activities and opinions, and teachers' performance were documented. The teacher and the students were then interviewed to know their responses towards the use of contextual teaching and learning approach.

After the action and observation are done, the researchers and the teacher collaborator conduct reflections which aim to decide whether or not the research cycle is continued. In this part, the researchers and teacher collaborator analyzed the qualitative and quantitative data obtained. Based on the result, the researchers and the English teacher determine whether the action work well in solving the reading problems.

The discussion of the action results is allotted in two sections, namely identification of the reading problems and the determination of actions to be taken. In the identification of the students' problems, this research was started by collecting initial information from the English teacher and some students. It was done by conducting interviews. Based on the result of the reconnaissance process, the field problems in the English teaching and learning process can be seen in Table 2.

Table 2. Field problems in English teaching and learning at the $8^{\text {th }}$ grade of SMPN 1 Jonggat

\begin{tabular}{lll}
\hline \multicolumn{1}{c}{ Items } & \multicolumn{1}{c}{ Problems } \\
\hline Reading Skills & $\circ$ Students felt difficulties in comprehending English texts. \\
& $\circ$ Students still had lack of vocabulary acquisition. \\
& $\circ$ Students lacked the English grammatical knowledge to understand English \\
& texts. \\
& $\circ \begin{array}{l}\text { Instead of making reading strategies, students tented to translating every } \\
\text { single word of the texts. }\end{array}$
\end{tabular}


Attitude, Motivation, and Participation

Instructional Activities
- A few of students had low motivation to learn.

- Students felt bored with usual learning activities of increasing reading skills.

- In the discussion session, some students looked passive and simply wrote the answer down to each comprehension tasks.

- A few of students did not focus on the teacher's explanation and they looked busy chatting with their tablemate.

- Some students did not accomplish the tasks given by the teacher.

- The learning activities were less interesting.

- Sufficient teaching media is not used in the learning and teaching activities.

- The interaction among students and between the teacher and the students was limited.

- The instructional strategies applied were not suitable for the students' interest.
Considering these problems, the researchers and the teacher decided the students' feasible problems to be taken. As the focus of this study was to improve students' reading comprehension in relation to motivation to learn, therefore the selected problems are difficulties in comprehending English texts, lack of vocabulary acquisition, lack of English grammatical knowledge to understand English texts, minimizing the translation of every single word in the texts, and improving the interaction among students and between the teacher and students. Besides, the students' problems relating to motivation were students had low motivation to learn and the discussion session does not make students be more active.

The next step is the determination of the action to be applied to tackle the selected problems to be solved. The researcher and the English teacher agreed in using contextual teaching and learning (CTL) approach with certain learning strategies that consisted of modeling, questioning and inquiry, learning community and constructivism, authentic assessment, and reflection. The main component of the learning strategy is the content of the text provided for students should direct them to learn actively. The complete instructional stages of the CTL approach are illustrated in Table 3.

Table 3. The teaching steps of the CTL approach for teaching reading

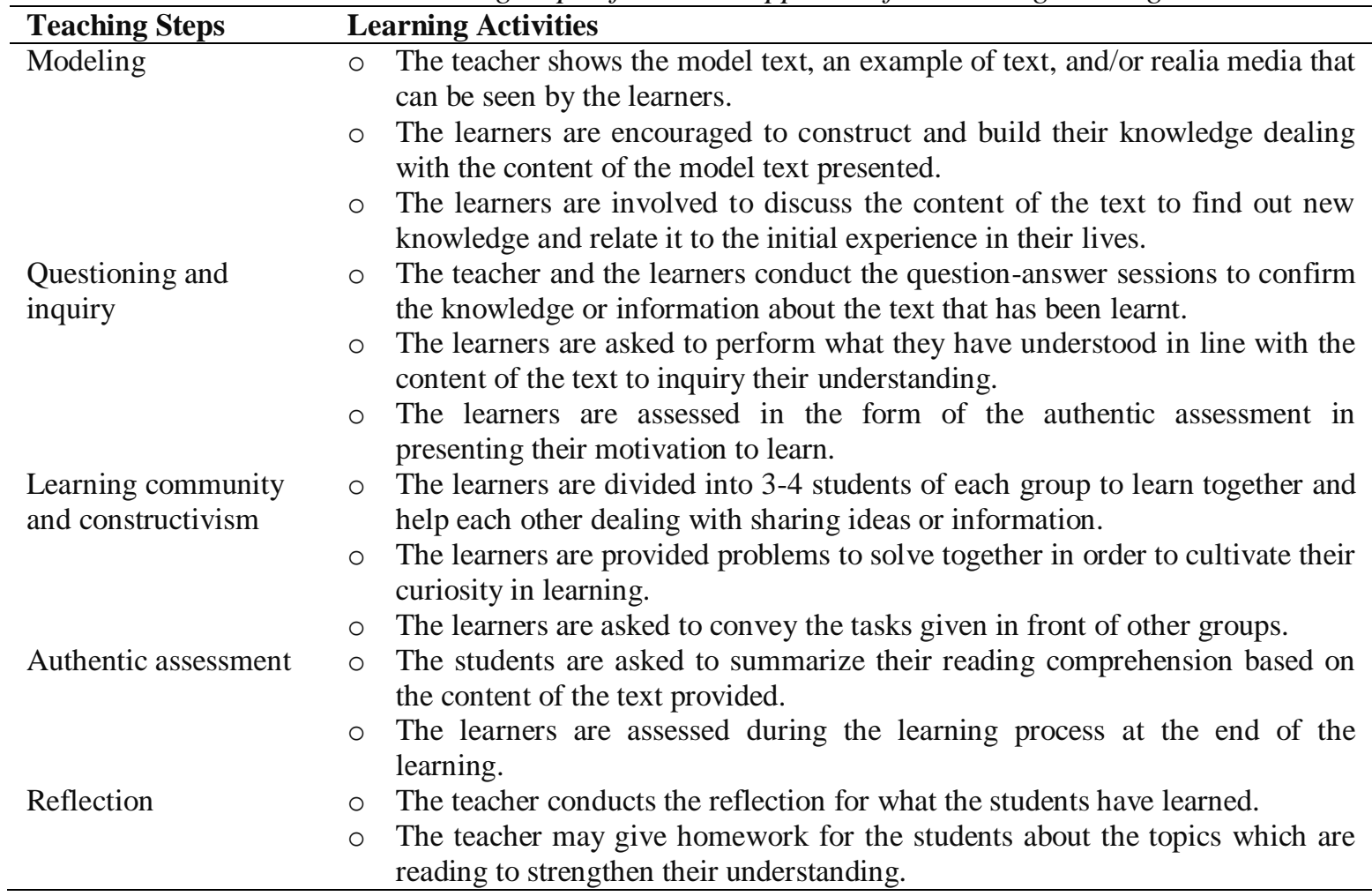


The teachers and students' roles in employing CTL are discussed by the researchers and the collaborator. The researchers gave chances for the English teacher and the students to express their point of views related to English instruction. Thus, the validity was reached by working collaboratively to determine problems for reading skills and the solution was found in line with the research problems. The action consisted of two cycles, Cycle 1 and Cycle 2. This study followed the cyclical action research consisting of planning, acting, observing, and reflecting. In addition, the instructional approach applied in this action was CTL approach. During the actions, the researchers acted as observers, while the English teachers acted as the teacher. Besides, the researchers involved their fellow university students to document the research process.

In this phase, the researchers provide an analysis of the findings from Cycle 1 and Cycle 2. Cycle 1 was done in four meetings and Cycle 2 was also carried out in four meetings. Each cycle had different problems to be solved. The aim of this study is to find out whether or not the implementation of CTL approach is able to improve students' reading comprehension viewed from motivation to learn at the $8^{\text {th }}$-grade students of SMPN 1 Jonggat. Based on the result of the observation sheet, the students' reading achievement was 64. This result was at the sufficient level. The passing grade is 70 . It means that the students' reading comprehension was lower than the passing grade.

The researchers and the teacher agreed to apply the existing curriculum employed in the school. The teams work collaboratively to create the lesson plan, teaching materials, teaching media, and the time schedule of English learning. In the actions, the instructional materials are adopted from the course-book used by the $8^{\text {th }}$ grade students of SMPN 1 Jonggat. The teams modified some topics in line with the ELT instructional and teaching goals.

In Cycle 1 the students are involved to build their knowledge. They are asked to notice and analyse some modelling texts. It is aimed at building students' knowledge of the text. In addition, the learners are involved to discuss the content of the text to find out new knowledge and relate it to the initial experience in their lives. It is in line with Surdin (2018) who states that giving contextual clues is important to facilitate students to comprehend unfamiliar words from the texts.
The first stage of CTL is oriented to build students' background knowledge. The topic of the reading text is made to be as familiar as possible for them before they are asked to do more learning activities. To help students carry out learning activities in this step, teachers provide some unfamiliar vocabularies. Besides, students are asked to write some phrases or idioms existing in the text. This learning activity motivates students to read more and more. It is in line with Marinak, Malloy and Gambrell (2010) and Ilahiyah et al. (2019) who state that motivated readers are curious and anxious readers to talk more what they are reading.

After students have the background knowledge of the text, they are asked to create questions relating to contents of the text. It is the second phase of CTL approach, namely the phase of questioning and inquiry. In this phase, students are directed to conduct a discussion concerning the text. The teacher and the students conduct the question-answer sessions to confirm the knowledge or information about the text that has been studied. To strengthen the students' information, they are asked to perform what they have understood in line with the content of the text. Then, the students used the context as clues in predicting unknown vocabularies. Although the students are not told the meaning of the words immediately, the students guessed their meaning. At the same time, the students are assessed in the form of the authentic assessment in presenting their motivation to learn. In Cycle 1 , the questioning and inquiry phase was not really effective to build students' background knowledge. It looked effective in Cycle 2.

To improve students' vocabulary acquisition and grammatical knowledge, the students are involved in analyzing the content of the text being read. These activities are done in the phase of the learning community and constructivism. Learning community is designed by the researchers to facilitate students to express their opinions concerning the text. In doing so, the students are divided into 3-4 students to learn together and help each other. In the class, the students are provided problems to solve together in order to cultivate their curiosity in learning. It was in line with what Fadhilah, Effendi, and Ridwan (2017) and Sufianto (2019) found that this stage involves students to learn actively. At the end of learning activities in this phase, the students are asked to convey their tasks given in front of other groups. These activities helped students to cultivate their understanding of the 
text. The acquisition of vocabularies through learning communities was improved in Cycle 2. In Cycle 1, the students are directed only to discuss the content of the text, while the students' problems in vocabularies and the grammatical knowledge are solved in Cycle 2.

Dealing with the students' motivation to learn, students looked keenly to learn reading tasks in Cycle 1. The students' motivation can be improved by providing them with different texts that make them curious about the content of the text. The motivation has a positive effect on ELT learning process (Sebet, Tahriri, \& Haghi, 2014; Hayes, 2009) For instance, in the phase of authentic assessment the students are asked to summarize their reading comprehension based on the content of the text provided. Students are able to summarize the text given in the class. Besides, the result of the interview showed that the students' response was positive in attending the reading class using CTL approach. Nevertheless, in Cycle 1 the students are assessed during the learning process at the end of the learning. It may lead students to have high motivation to accomplish and learn the reading tasks given by the teacher.

In the phase of reflection, students are asked to reflect what they have learned. The texts are reread more than once so as to have a good understanding of its content and context. At the end of the learning phase, the teacher gives homework for the students in order to strengthen their understanding. It is very useful for them to build their knowledge and enrich their information dealing with the topic being read (Khaefiatunnisa, 2015). It is also applied in improving grammatical knowledge and has a positive effect (Hasani, 2016).

Further, the researchers did an evaluation which aims to analyze students' reading achievement and motivation. In Cycle 1, some students' problems were solved and others were handled in Cycle 2. For instance, the interaction between students and the teacher and among students occurred in Cycle 1, but it was not so effective. Based on these findings, the researchers and the teacher decided to solve this problem in Cycle 2.

Lastly, the use of contextual teaching and learning was effective to improve students' reading comprehension. This approach directed students to comprehend texts based on the content. The role of text in CTL also provides students with activities to train their metacognitive awareness (Al-Mekhlafi, 2018). In comprehending an English text, translating every single word is not a sole strategy. Instead, they should utilize their background knowledge and metacognition to predict the content of the text. In addition, CTL approach is able to connect between students' background knowledge and their ability to identify and analyze the implied meaning from the text. It is in line with what Haryati (2017) found that prediction served as students' reading purpose and promoted the students' critical thinking in the reading class. Fostering reading purposes and critical thinking reading is assumed to be one of the strategies to improve comprehension.

\section{CONCLUSION}

From the analysis, it can be concluded that the use of contextual teaching and learning (CTL) is able to improve students' reading comprehension and motivation. This approach has five teaching phases, namely modeling, questioning and inquiry, learning community and constructivism, authentic assessment, and reflection. In Cycle 1, the researchers and the teacher carry out actions in four meetings. The fifth meeting was conducted for the final test of reading comprehension. The effect of contextual teaching and learning approach in the $1^{\text {st }}, 2^{\text {nd }}$, and $3^{\text {rd }}$ meetings was not yet effective. The effect of the CTL approach can be seen in the fourth meeting. The average score of students' achievement was 75. It means that the minimum achievement criteria (KKM) were attained. The important change in each cycle was that students were able to reduce their learning difficulties through reading activities based on the context and content. Besides, it was also able to influence students' motivation to learn.

The research findings show that contextual teaching and learning (CTL) is useful and fruitful to enhance students' reading comprehension in relation to motivation to learn. Therefore, it is suggested that English teachers who intend to improve reading skills can apply and explore more deeply CTL approach. The English teacher can keep going to apply this approach in ELT classes at the junior secondary schools because it can help students to minimize their learning problems. The important thing for English teacher is that CTL approach cannot be employed only within a group as what this study did but also in pairs or individually considering the students' English reading proficiency.

During the research, the researchers and the English teacher found the difficulties to provide 
ENGLISH REVIEW: Journal of English Education

Volume 8, Issue 1, December 2019

students with various interesting materials to read in relation to themes of the reading texts. Therefore, it is suggested that other researchers prepare more interesting and various themes.

\section{REFERENCES}

Alqatanani, A. K. (2017). Do multiple intelligences improve EFL students' critical reading skills? Arab World English Journal, 8(1), 309-321.

Al-Mekhlafi, A. M. (2018). EFL learners' metacognitive awareness of reading strategies. International Journal of Instruction, 11(2), 297308. doi: 10.12973/iji.2018.11220a.

Badan Standar Nasional Pendidikan (BSNP). (2013). Materi bimbingan teknis KTSP dan soal terstandar 2010: Panduan analisis butir soal. Jakarta: Kementrian Pendidikan Nasional.

Camp, D. V., \& Camp, W. V. (2013). Using content reading assignment in a psychology course to teach critical reading skills. Journal of the Scholarship of Teaching and Learning, 13(1), 86-99.

Cohen, L., Manion, L., \& Morrison, K. (2018). Research methods in education ( $8^{\text {th }}$ ed.). London: Routledge Taylor \& Francis Group.

Fadhilah, F., Effendi, Z. M., \& Ridwan, R. (2017). Analysis of contextual teaching and learning (CTL) in the course of applied physics at the mining engineering department. International Journal of Science and Applied Science: Conference Series, 1(1), $25 . \quad$ doi: 10.20961/ijsascs.v1i1.5106.

Haerazi. (2017). Genre-based language learning model in teaching writing skills for English department students. International Conference, 109(Aecon), 108-111. doi: 10.2991/aecon-17.2017.22.

Haerazi, Irwansyah, D., Juanda, \& Azis, Y. A. (2018). Incorporating intercultural competences in developing English materials for writing classes. Journal of Language Teaching and Research, 9(3) 540-547. doi: 10.17507/jltr.0903.13.

Haryati, S. (2017). Hoax news: Promoting the students' critical thinking in critical reading class. REGISTER Journal, 10(2) 122-139. doi: 10.18326/rgt.v10i2.122-139.

Hasani, A. (2016). Enhancing argumentative writing skills through contextual teaching and learning. Educational Research and Reviews, 11(16), 1573-1578. doi: 10.5897/ERR2016.2806.

Hayes, C. (2009). Student motivation, blended learning \& an iPod project in tertiary Japanese language teaching at ANU. Electronic Journal of Foreign Language Teaching, 6, 230-244.

Hosnan, M. (2014). Pendekatan scientific dan contextual dalam pembelajaran abad 21. Bogor: Ghalia Indonesia.

Ilahiyah, A. I., Andina, D. M., Tiven, P. A., \& Chayono, B. Y. (2019). Indonesian EFL students' reading motivation and writing achievement across gender. EduLite: Journal of
p-ISSN 2301-7554, e-ISSN 2541-3643

https://journal.uniku.ac.id/index.php/ERJEE

English Education, Literature, and Culture, 4(2) 119-131. doi: 10.30659/e.4.2.119-131.

Khaefiatunnisa. (2015). The effectiveness of contextual teaching and learning in improving students' reading skill in procedural text (A quasi-experimental study of the second grade students at one vocational school in Bandung). Journal of English and Education, 3(1), 80-95.

Marinak, B., Malloy, J., \& Gambrell, L. (2010). Engaging readers: Research-based practices that nurture the motivation to read. International Journal of Learning, 17(5).

Mursyid, M., \& Kurniawati, N. (2019). Higher order thinking skills among English teachers across generation in EFL classroom. English Review: Journal of English Education, 7(2), 119-124. doi: 10.25134/erjee.v7i2.1775.

Nugrahani, V. E. (2018). Intrinsic and extrinsic motivation found in students' written reflection in play performance course. Indonesian Journal of EFL and Linguistics, 3(2), 171. doi: 10.21462/ijefl.v3i2.79.

Par, L. (2018). The EFL students' critical reading skills across cognitive styles. Journal of JEELS, $5(1)$.

Satriani, I., \& Emilia, E. (2012). Contextual teaching and learning approach to teaching writing. Indonesian Journal of Applied Linguistics, 2(1) $10-20$.

Sufianto. (2019). The effect of contextual teaching and learning (CTL) learning model on the ability of concept understanding class VII students of SMP 16, Kota Bengkulu. Jurnal Pendidikan Matematika Raflesia, 4(1), 19-28. doi: 10.33449/jpmr.v4i1.7525.

Sultan, Rofiuddin, A., Nurhadi, \& Prihatni, E. T. (2017). The effect of the critical literacy approach on pre-service language teachers' critical reading skills. Eurasian Journal of Educational Research, 71, 159-174.

Surastina, \& Dedi, F. S. O. (2018). Examining academic writing motivation of prospective Indonesian language teachers using exploratory factor analysis. International Journal of Instruction, 11(2), 15-24. doi: 10.12973/iji.2018.1122a.

Surdin. (2018). The effect of contextual teaching and learning (CTL) models on learning outcomes of social sciences of the material of forms the face of the earth on Class VII of Junior High School. International Journal of Education and Research, 6(3), 57-64.

Syahid, U., \& Tuharto. (2015). Studi komparasi model pembelajaran matematika dengan pendekatan saintifik dan pendekatan kontekstual ditinjau dari kemampuan pemecahan masalah, Jurnal Pendidikan Matematika dan Sains, 4.

Thamrin, N. R., \& Agustin, S. (2019). Conceptual variations on reading comprehension through higher order thinking skills (HOTS) strategy. 
Haerazi, Zukhairatunniswah Prayati, \& Rully May Vikasari

Practicing contextual teaching and learning (CTL) approach to improve students' reading comprehension in relation to motivation

English Review: Journal of English Education, 7(2), 93-100. doi: 10.25134/erjee.v7i2.1777.

Tsai, P., Chen, S., Chang, H., \& Chang, W. (2013).

Effect of prompting critical reading of science news on seventh graders' cognitive development. International Journal of Environmental \& Science Education, 8(1), 85-107. 